\title{
FOOD SAFETY LEGISLATION REGARDING OF AFLATOXINS CONTAMINATION
}

\author{
KETNEY Otto \\ Lecturer Ph.D. Eng., Faculty of Agricultural Sciences, Food Industry and Environmental Protection, \\ “Lucian Blaga” University of Sibiu, Sibiu, Romania, e-mail: otto_ketney@yahoo.com
}

\begin{abstract}
The main objective of the European Union (EU) is to reduce certain contaminants in foodstuffs to acceptable levels. The occurrence of aflatoxin B1 in food was considered to be one of the most important issues of global food security to protect the health of humans and animals, over 100 nations have established maximum tolerable levels for aflatoxin in food. Although EU legislation covers many aspects of food safety was not legally establish an integrated framework that could effectively combat and cover all sectors of the food chain. Monitoring and reporting levels of aflatoxins after controls are essential actions that assist to identify potential risks to human health. The review process for aflatoxin regulations is a complex activity involving many factors and stakeholders.
\end{abstract}

Keywords: Food safety, aflatoxin, legislation

\section{Introduction}

Food safety is considered to be an important issue for all stakeholders in food production. Consumers and other stakeholders are increasingly concerned about the continuous sequence of food scandals and incidents [1]. These scandals often get broad coverage in the media and in professional publications. As a result, consumers are familiar with ESB, dioxin, AMF, etc., and other contaminants that were widespread in food because of errors in production processes or associated with the use of contaminated raw materials or means of production.

Consumer perceptions looks thus concern over food safety and the food they buy properties and eats them. Although much information is available as a result of the conventions of etiquette, this does not always lead to more confidence. It is important for the food industry to protect trademarks in order to restore and maintain consumer confidence.

Food industry is very vast and is in direct contact with humanity, it is indispensable because food is basic subsistence population. For this reason it should be considered every step of the production phase, transport, storage of each product that reaches the final consumer, man. Food safety is a top priority for the EU. This new integrated approach - feed and food are carefully tracked from "FROM FARM TO FORK".[2]

Considering food safety problems and dangers that people may be exposed, they are classified [3]:

- naturally occurring chemical materials such as mycotoxins, toxins from fungi, toxins in shellfish toxins in potatoes sprouting, biogenic amines formed in old or spoiled foods and those that do not alter the sensory properties of food)

- chemical substances added (agricultural chemicals (pesticides, fungicides, fertilizers, insecticides, antibiotics, growth hormone) from the degradation of various substances chloride base materials, which accumulate in the grass and end up in the body of animals, toxic metals and combinations their substances from equipment and utensils: cleaning and disinfection agents, coating materials, paints, food additives, chemicals intentionally added).

However in foods can be may hold a number of chemical compounds which are toxic, which may influence consumer health, including greenhouse substances on food micotoxicogen enumerate and 
aflatoxins which are produced by biosynthesis of Aspergillus species, Aspergillus flavus including Aspergillus parasiticus and Aspergillus nomius developed on a substrate, producing illness to those who consume the product. However mycotoxins aflatoxin is the type most commonly found in cereals [4] .

Aflatoxins were first identified in 1961 in feed as a result of the death of 100,000 turkeys in Britain [5]. Therefore the aflatoxin B1 is established as one of the most toxic compounds identified as a factor that causes cancer, so it was classified as (Group 1) by the International Agency for research on Cancer (IARC) [6].

The occurrence and biosynthesis of aflatoxins varies by geographic area and climate, therefore aflatoxin contamination can generally occur in countries with warm climates, and poor hygiene, mold and improper storage conditions [7]. However occurrence of aflatoxin B1 in food is considered to be one of the most important issues of global food security [8].

A variety of food products may be contaminated with aflatoxin, the most recent studies refers to:

- cereals [9-11]

- $\quad$ spices [12]

- Coffee [13]

- peanuts [14]

- dairy products [15-17]

- dried fruit [18]

- herbs [19]

Food safety legislation usually set at national / European level is mainly limited to aflatoxin, aflatoxin B1 which is classified as a potent carcinogen.

\section{The current EU legislation}

In proportion as globalization gaining momentum, pressure from products from emerging countries which benefit from low production costs, the farmers in the EU is growing. Both agricultural commodities and value-added products face competition from increasingly higher. Faced with these new commercial challenges, the European farmer's main asset is quality. The EU has an advantage on quality, which is due to a very high level of safety ensured by EU legislation throughout the entire food chain, from which farmers and generally producers. There are still many aspects which can reinforce quality in the broadest sense of the term. Quality is an issue for every farmer and every buyer, whether dealing with commodities produced to baseline standards or with high-quality products that excel in Europe.[20]

Market requirements are increasingly diverse and more. In the European Union, the most important aspects are hygiene and food safety (a 'non-negotiable'), health and nutritional value, and societal demands. Also, consumers are increasingly aware of the contribution of agriculture to sustainability, climate change, food security and development, biodiversity, animal welfare, and water scarcity. As the first user of land, farming is a key factor in the territorial development of regions, landscapes and valuable environmental areas. Finally, in many parts of the world, growing disposable income consumers are demanding in terms of taste, tradition and authenticity of the food they consume, and in terms of compliance with higher standards animal welfare[21]

The occurrence of aflatoxin B1 in food was considered to be one of the most important issues of global food security [8]. To protect human and animal health, over 100 nations have established maximum tolerable levels for aflatoxin in food [22]. Therefore, more than 99 countries have established regulations for aflatoxin B1 and the sum of aflatoxin B1, aflatoxin B2, aflatoxin Gl and G2 in food and agricultural food. Therefore these limits were set in order to reduce contamination in food and feed. Therefore maximum permitted levels (MPL) for aflatoxin B1, aflatoxin M1, and the sum of aflatoxins B1, B2, G1 and G2 in food are laid down in Regulation (EC) no. 1881/2006 (EC) [23] amended by Regulation (EU) No 165/2010 [24] and Regulation (EU) No. 1058/2012 [25]. This Regulation establishes maximum levels of certain contaminants: nitrates, mycotoxins (aflatoxins, ochratoxin A, patulin and Fusarium toxins), heavy metals (lead, cadmium, mercury), monochloropropane-1, 2-diol (3-MCPD), dioxins and dioxin-like PCBs, polycyclic aromatic hydrocarbons (PAH) and inorganic tin. Foods with higher contaminant levels than those specified in Annex Regulation cannot be marketed. These maximum levels refer to the edible parts of food and similarly apply to compound foods or processed, dried or diluted, possibly by a factor of dilution or concentration or by considering the relative proportions of the ingredients in the product compound. In addition, the Regulation sets maximum levels of contaminants to 
the lowest level enabling reasonably good manufacturing or agricultural practices (ALARA, the lowest level possible)[26].

In the case of animal feed aflatoxin contamination level is governed by Commission Regulation No 574/2011 of 16 June 2011 on undesirable substances in animal feed. This Regulation provides that the maximum AFB1, a feed with a moisture content of 12\%, ranging from 5 to $20 \mathrm{pg} \mathrm{Kg}$. However some countries have a number of limitations, often dictated by the feed destination. From the point of view of human health, the stricter criteria apply to feed for dairy cows because AFB1 in AFM1 conversion (MPL $=5 \mathrm{~g} \mathrm{Kg}^{-1}$ across the EU).

Because aflatoxins found in food nature, it is not possible to impose a total ban thereof. Therefore, it was necessary to take measures restricting the maximum concentration, minimizing any risk to human health. Shares exclusion limits in food and feed should be imposed. In this context, a number of regulatory limits have been established by national, regional and international databases of scientific and socio-economic data. This is reflected by EC Regulation 165/2010 increasing certain levels for certain foodstuffs, compliance, while the EU agreement with the WTO.

\section{Harmonization of legislation}

European policy on food security has two main objectives: protecting human health and consumer interests and promote the smooth functioning of the single European market. The European Union shall ensure that rules are established and achieved control in areas such as food and feed hygiene, animal health, plant health and prevention of food contamination by foreign substances. Union also regulates the labeling of food and feed.[27]

Agri-food sector is of major importance for the European economy as a whole. Food and beverage industry is a leading industrial sector in the EU, with an annual production worth almost 600 billion, or about $15 \%$ of total manufacturing. An international comparison presented by the EU is the world's largest producer of food and beverages. Food and beverage industry is the third largest industrial employer in the EU with over 2.6 million employees, of which $30 \%$ are small and medium enterprises. On the other hand, the agricultural sector has an annual production of about 220 billion and provides the equivalent of 7,5milioane job full time. Exports of agricultural products, food and drinks are worth about 50 billion a year. The economic importance and the ubiquity of food in our life suggest that there must be a prime interest in food safety in society as a whole, and in particular by public authorities and producers[28].

The European Union has a broad body of legislation which covers primary production of agricultural products and industrial production of processed food. The legislation has evolved over the last thirty years, reflecting a blend of scientific forces, social, political and economic, in particular the creation of the internal market, but this development was not consistent and globally. For this reason, the Green Paper on the general principles of food law in the European Union has already set need a major overhaul of food legislation.

Food production is extremely complex. Products intrinsic hazards of animal and vegetable because of microbiological and chemical contamination. The real problem is not necessarily due to lack of legal instruments, but are large differences in the means to respond to situations in specific sectors, or the multiplicity of actions to be triggered if a problem flows from one sector to another . One of the weakest links in the system is the lack of a clear commitment from all interested parties to give an early warning about a potential risk, so that measures scientific evaluation and the necessary protection can be triggered early enough to ensure a proactive response rather than reactive in the EU.

Recent decades have seen a significant acceleration of globalization of the food supply. As the world progresses in the XXI century, supply systems are undergoing changes at an unprecedented pace, driven by economic and social exchanges worldwide [29]. Increased complexity, interdependence and integration of modern food supply have been raised in recent years.

Despite immediate reaction from national governments to narrow the legislation and to restore consumer confidence diminishing effect of such major food safety crises can have no other result than to emphasize the critical need for urgent global harmonization of laws food safety and regulation. As the world grows more closely linked so that the impetus for the harmonization of food safety regulations and achieve a global consensus on their founding principles [30]. 


\section{Improve food security policy}

Although EU legislation covers many aspects of food safety was not legally establish an integrated framework that could effectively combat and cover all sectors of the food chain as a whole, from primary production to retail sale and as the authority single that could provide rigorous scientific advice for food risks [31]. Therefore this gap was addressed for the first time in "Green Paper" European Commission [32] of food law (1997), this approach was followed by the "White Paper" food safety [33], one of the most important milestones in the history of EU food policy, which was issued in 2000.

Following the White Paper the Commission proposed a new legal framework. It covers the entire food chain including animal feed production, it also establishes a high level of health protection for consumers that clearly assigns responsibility for safe food production to industry, producers and suppliers.

The Commission regularly visit the Member States, and pointed out that there are wide variations in how legislation is being implemented and enforced. This means that consumers cannot be sure the same level of protection throughout the community. It is proposed that, in cooperation with Member States, to develop a Community framework for the development and operation of national control systems.

Control on imports at Community borders will be extended to cover all feed and food, as well as measures taken to improve checkpoints.

\section{Conclusions}

Despite immediate reaction from national governments to narrow the legislation and to restore consumer confidence reduction in aflatoxin contamination has resulted in a recent review of stricter limits, so the European Commission asked the European Food Safety Authority (EFSA) - the body of EU risk assessment for food and feed safety to give its opinion on the possible adverse effects in humans after an increase of limits for certain types of nuts. EFSA conclusion possible to increase and limits are higher. However, differences between general regulatory limits and regulations of developed countries and developing still exist reflecting socio-economic criteria.

EU food legislation must also respond to changes in the way food is produced and changes in consumer preferences. Attempts to make progress in these fields at EU level have not always proved successful. Given that consumers in different Member States are not all likely to want the same things at the same time, and given that there will always be tension between the economic needs of producers and consumers' reluctance to accept innovations in technology and science food production, Community legislation aims to standardize rules on these matters will prove to be a difficult task.

The establishment of a European Food Safety Authority will strengthen scientific and technical support system already in place, a system that was recognized, it was not able to respond to growing demand. In accordance with the general principles of food law also provided for in the Regulation, the Authority should take on the role of an independent scientific point of reference in risk assessment and thus help the smooth functioning of the internal market.

It will perform this role through its opinions on contentious scientific issues, thereby enabling the Community institutions and Member States to make informed decisions and risk management to ensure food and feed safety, while also helping to avoid fragmentation of the internal market through the adoption of unjustified or unnecessary obstacles to the free movement.

\section{Acknowledgements}

This work was supported by the strategic grant POSDRU/159/1.5/S/133255, Project ID 133255 (2014), co-financed by the European Social Fund within the Sectorial Operational Program Human Resources Development 2007 - 2013 


\section{References}

1. $\quad$ Dorp, V. and C.A., Reference-data modeling for tracking and tracing. Wageningen: Wageningen University.(2004)

2. Asmarndei Viorel, C.N., Gheorghiţă Vlad, Manual pentru efectuarea controlului ofi cial al unităţilor din domeniul alimenta, in ansa.gov.md.(2013)

3. Berechet, G. Planul de siguranța alimentelor pe baza principiilor HACCP. in Conferința HRB Expert. București.(2006)

4. $\quad$ Otto, K., Cercetări privind posibilităţile de reducere a Aflatoxinei $M$ din produsele lactate prin utilizarea unor metode biotehnologice moderne Sibiu: Editura Universităţii "Lucian Blaga" din Sibiu. 220.(2015)

5. $\quad$ Sargeant, K., et al., Toxicity associated with certain samples of groundnuts.(1961)

6. IARC Working Group on the Evaluation of Carcinogenic Risks to Humans , World Health Organization, and International Agency for Research on Cancer Some Traditional Herbal Medicines, Some Mycotoxins, Naphthalene and Styrene: Some traditional herbal medicines, some mycotoxins, naphthalene and styrene. World Health Organization.(2002)

7. Trucksess, M. and P. Scott, Mycotoxins in botanicals and dried fruits: a review. Food additives and contaminants. 25(2): p. 181-192.(2008)

8. Shim, W.-B., et al., Development of immunochromatography strip-test using nanocolloidal goldantibody probe for the rapid detection of aflatoxin B1 in grain and feed samples. Journal of microbiology and biotechnology. 17(10): p. 1629-1637.(2007)

9. Berthiller, F., et al., Chromatographic methods for the simultaneous determination of mycotoxins and their conjugates in cereals. Int J Food Microbiol. 119(1-2): p. 33-7.(2007)

10. Pereira, V.L., J.O. Fernandes, and S.C. Cunha, Mycotoxins in cereals and related foodstuffs: A review on occurrence and recent methods of analysis. Trends in Food Science \& Technology. 36(2): p. 96-136.(2014)

11. Rodriguez-Carrasco, Y., et al., Exposure estimates to Fusarium mycotoxins through cereals intake. Chemosphere. 93(10): p. 2297-303.(2013)

12. Khayoon, W.S., et al., Micro-solid phase extraction with liquid chromatography-tandem mass spectrometry for the determination of aflatoxins in coffee and malt beverage. Food Chem. 147: p. 287-94.(2014)

13. Kaya-Celiker, H., et al., Discrimination of moldy peanuts with reference to aflatoxin using FTIRATR system. Food Control. 44: p. 64-71.(2014)

14. Scaglioni, P.T., et al., Aflatoxin B(1) and M(1) in milk. Anal Chim Acta. 829: p. 68-74.(2014)

15. Afshar, P., et al., Occurrence of Ochratoxin A and Aflatoxin M1 in human breast milk in Sari, Iran. Food Control. 31(2): p. 525-529.(2013)

16. Anfossi, L., et al., Occurrence of aflatoxin M1 in Italian cheese: Results of a survey conducted in 2010 and correlation with manufacturing, production season, milking animals, and maturation of cheese. Food Control. 25(1): p. 125-130.(2012)

17. Bilandžić, N., I. Varenina, and B. Solomun, Aflatoxin M1 in raw milk in Croatia. Food Control. 21(9): p. 1279-1281.(2010)

18. Beheshti, H.R. and M. Asadi, Aflatoxins in sunflower and safflower seeds from Iran. Food Additives and Contaminants: Part B. 6(1): p. 68-71.(2013)

19. Prandini, A., et al., On the occurrence of aflatoxin $M 1$ in milk and dairy products. Food and Chemical Toxicology. 47(5): p. 984-991.(2009)

20. Commission, E., agriculture, in http://ec.europa.eu/.(2008)

21. eur-lex, eur-lex.europa, in eur-lex.europa.(2008)

22. $\mathrm{Wu}, \mathrm{F}$. and $\mathrm{H}$. Guclu, Aflatoxin regulations in a network of global maize trade. PloS one. 7(9): p. e45151.(2012)

23. Commission, E., Commission Regulation (EC) No 1881/2006 of 19 December 2006 setting maximum levels for certain contaminants in foodstuffs (Text with EEA relevance) in 1881/2006, E. Commission, Editor.,(2006)

24. Commission, E., Commission Regulation (EU) No 165/2010 of 26 February 2010 amending Regulation (EC) No 1881/2006 setting maximum levels for certain contaminants in foodstuffs as regards aflatoxins in 1865/2010, E. Commission, Editor.,(2010) 
25. Commission, E., Commission Regulation (EU) No 1058/2012 of 12 November 2012 amending Regulation (EC) No 1881/2006 as regards maximum levels for aflatoxins in dried figs, in 1058/2012, E. Commission, Editor.,(2012)

26. Uniunea Europeană Regulamentul (CE) nr. 1881/2006 din 19 decembrie 2006 de stabilire a nivelurilor maxime pentru anumiţi contaminanţi din produsele alimentare, in Reg. CE. 1881/2006, C. Europena, Editor., C Uniunea Europeană, http://eur-lex.europa.eu/, 1998-2014: Bruxelles.(2006)

27. Vicario, L., siguranta alimentara, in europarl.europa.eu.(2014)

28. European Commission, White paper on food safety. Office for Official Publications of the European Communities.(1999)

29. Food Agriculture Organization of the United Nations, Globalization of Food Systems in Developing Countries: Impact on Food Security And Nutrition. Fao Food \& Nutrition Paper. Food and Agriculture Organization of the United Nations.(2004)

30. Motarjemi, Y., M. vanschothorst, and F. Käferstein, Future challenges in global harmonization of food safety legislation. Food Control. 12(6): p. 339-346.(2001)

31. European Commission. 50 years of food safety in the European Union, Health and Consumer Protection Directorate-General. Available from: http://ec.europa.eu/food/food/docs/50years_foodsafety_en.pdf.(2007)

32. European Commission. The General Principles of Food Law in the European Union. Commission Green Paper. COM (97) 176 final, 30 April 1997. Available from: http://aei.pitt.edu/1182/1/food law gp COM 90 218.pdf.(1997)

33. European Commission. White Paper on Food Safety. Available from: http://ec.europa.eu/dgs/health_consumer/library/pub/pub06_en.pdf.(2000) 